\title{
Evaluating the Significance of Financial Characteristics on Energy Consumption of Urban Building Stock using Principal Component Analysis and Logistic Regression
}

\author{
Vishnu Sivarudran Pillai, Arathi KV
}

\begin{abstract}
The increased population and the rapid urbanization seek our attention towards sustainable production and consumption in cities. In assessing the factors affecting the energy consumption characteristics of the buildings, it is crucial that we consider the user behavior along with the design characteristics of the buildings. One significant factor that influence the user behavior is the financial characteristics. We use non-parametric machine learning algorithms and econometric models to assess the influence of the user behavior characteristics in the urban building stock in New York City. The analysis was conducted on the open-data assessable, which is mandated by the Local Law 84. In our analysis we concluded that the financial characteristics have a significant effect in the energy consumption of the residential buildings, however, is not that significant in deciding the energy consumption of the commercial buildings.
\end{abstract}

Keywords: Building Energy, Principal Component Analysis, Logistic Regression, Energy Usage Intensity.

\section{INTRODUCTION}

$\mathrm{T}$ he fifth IPCC report on the impacts of global warming emphasizes the need for global attention on the issue of climate change. The report reaffirms that the way the buildings use energy has a significant influence on climate supplying energy is an important reason for the rise in global energy consumption and one-third of greenhouse gas emissions [1]. It is therefore important that various factors effecting the building energy consumption be studied. Studies related to the energy consumption of buildings can be performed using simulations and experiments [2]. Such studies can answer specific design issues (such as those related to ventilation) and has got higher internal validity however lacks external validity. In the era of open data, there is an oppurtunity for more non-experimental research to understand the energy consumption of building stock and to test various hypotheses to arrive at design and regulatory decisions to minimize the energy consumption. It is in this regard that data-driven energy bench marking models became

Revised Manuscript Received on July 05, 2020.

* Correspondence Author

Vishnu Sivarudran Pillai*, Department of Public Policy, The Hong Kong University of Science and Technology, Clear Water Bay, Kowloon, Hong Kong.. E-mail: vsp@ connect.ust.hk arathinairkallaniyil@gmail.com change. Carbon pollution due to the burning of fossil fuels for temperature. Buildings account for $40 \%$ increase in overall

Arathi KV, Ezra Homes, Kochi, Kerala, India. E-mail:

more prominent. A data-driven bench marking model was developed by Yang, Roth and Jain in 2018 [3] to filter the most inefficient building in a building stock. Ma and Cheng in 2016 [4] used random forest to understand the most influential factors in the energy consumption of buildings in a building stock. However, their approach does not address the design and regulatory characteristics pertaining to the energy efficiency of the buildings. The control of design for energy efficiency of buildings must move towards "Design for Energy Efficiency" (DFEE), which depends on the user behavior and the building structure characteristics. It is very difficult to understand the effect of such characteristics as these characteristics does not exist in isolation. For the ease of analysis, researchers tends to consider residential and commercial buildings separately and focus on measures for improving energy efficiency. However the previous works [3], [5], [6] does-not consider the impact of typical user characteristics that enables policy interventions and promote design innovation. In this article we examined one aspect of the user characteristic which is financial characteristics on the building energy efficiency by using "Principal Component Analysis" and "Logistic Regression" .We tested the hypothesis that "the financial characteristics of the building stock has more significant effect on the energy consumption of residential buildings than in the commercial buildings". This is counter-intuitive in the sense that, commercial building owners will be more interested towards saving of energy consumption as that directly effects their profit. Such an analysis will help the town planning officials to address the issue of higher energy consumption by filtering design options that promote higher energy efficiency. In section 2, we portray the research design of the article. Section 3 deals with the results and discussions.

\section{RESEARCH DESIGN}

\section{A. Method}

To test the hypothesis, we used a non-experimental research design which comprises of Principal Component Analysis (PCA) and logistic regression. PCA is an unsupervised learning process and is considered as an effective method for exploratory data analysis and to handle missing values [7].

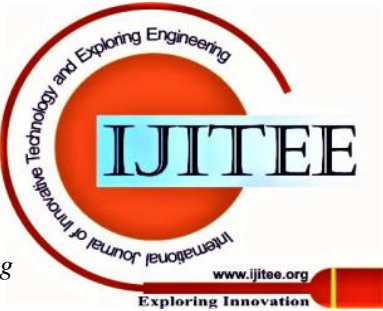


PCA reduces the dimensionality of data containing a broad set of variables. The initial variables are transformed into a new set of variables without losing the most essential information in the original data set. These new variables correspond to a linear combination of the originals and are called principal components. Principal components are orthogonal vectors. The first principal component is the eigenvector corresponding to the largest eigenvalue, the second is the next largest and so on. We then performed Hierarchical Clustering using Principal Components (HCPC) using the package "factomineR" in R Programming language [8], [9]. HCPC uses an agglomeration criteria that minimizes the increase of within- cluster inertia, which according to Huygens' theorem reduces the between-clusters inertia [9], [10]. This is explained in equation (1) [9]. Suppose a and b are the clusters with centre of gravity $g$ and $h$ and cluster size $s$ and $\mathrm{t}$, then in HCPC we choose a and b such that $\Delta(a, b)$ is minimized. $\Delta(a, b)$ is given by [9]:

$$
\Delta(a, b)=\frac{(s \times t)}{(s+t)} d^{2}(g, h)
$$

, where $d^{2}(g, h)$ is the Euclidean distance.

We then performed, "Proportional Odds Logistic Regression" (POLR) in the individual clusters using the package "mass" [11] in the R-programming language.

\section{B. Data and Selection of Variables}

We performed HCPC and logistic regression on the Local Law 84 (LL84) data reported on 2019. The LL84 requires reporting of the annual energy consumption by large commercial buildings (over 50000 sqft of gross floor area) [12]. This borough-wise energy usage data is then combined with the Primary Tax Lot Output (PLUTO) data from the New York City Department of Planning. The building characteristics are the independent variables and the "weather normalized site energy usage intensity" (weather site EUI) is the dependent variable. The building characteristics considered are gross floor area (in sq.ft), building class (represents the major use of the structures of the property), assessed total value(in \$), assessed land value(in \$), building area (in sq.ft), lot area (in sq.ft), number of buildings on the lot, number of floors, number of total units (the units in all buildings in the lot), number of residence units(the residential units in all buildings on the lot), total area ( the exterior dimensions of the structure for commercial use in sq.ft and the exterior dimension of the structures for residential use in sq.ft), year built ( the year building construction completed), building frontage ( the building frontage along the street in $\mathrm{ft}$.) and building depth ( the perpendicular distance in ft.) [13]. These independent variables are the variables loaded to obtain the dimensions in the HCPC. These characteristics are in align with the previous work carried out on the energy benchmarking [3] and similar studies on energy usage characteristics of urban building stocks [4]. The variable, building class was not considered in HCPC. Thus, the variables as shown in Table 1 are used for the HCPC. We considered 11931 buildings for HCPC. In the POLR, we examined the interaction of the building class with the other independent variables keeping weather site EUI as the dependent variable. We divided the weather site EUI into three levels, based on their values such that each level has equal number of buildings approximately.

Table- I: The building characteristics considered for the PCA [13]

\begin{tabular}{|c|c|}
\hline $\begin{array}{c}\text { Building } \\
\text { Characteristics }\end{array}$ & Description \\
\hline unitsres & $\begin{array}{l}\text { The sum of residential units in all buildings on } \\
\text { the tax lot. }\end{array}$ \\
\hline unitstotal & $\begin{array}{l}\text { The sum of residential and non-residential } \\
\text { (offices, retail stores, etc.) units for all } \\
\text { buildings on the tax lot }\end{array}$ \\
\hline numbldgs & The number of buildings on the tax lot. \\
\hline numfloors & $\begin{array}{l}\text { The number of full and partial stories starting } \\
\text { from the ground floor, for the tallest building } \\
\text { on the tax lot. }\end{array}$ \\
\hline bldgdepth & $\begin{array}{l}\text { The building's depth, which is the effective } \\
\text { perpendicular distance, measured in feet }\end{array}$ \\
\hline yearbuilt & $\begin{array}{l}\text { The year construction of the building was } \\
\text { completed }\end{array}$ \\
\hline bldgfront & $\begin{array}{l}\text { The building's frontage along the street } \\
\text { measured in feet. }\end{array}$ \\
\hline asssessland & The assessed land value for the tax lot \\
\hline totarea & The summation of the resarea and the comarea \\
\hline resarea & $\begin{array}{c}\text { An estimate of the exterior dimensions of the } \\
\text { portion of the structure(s) allocated for } \\
\text { residential use }\end{array}$ \\
\hline comarea & $\begin{array}{c}\text { An estimate of the exterior dimensions of the } \\
\text { portion of the structure(s) allocated for } \\
\text { commercial use }\end{array}$ \\
\hline assesstot & The assessed total value for the tax lot. \\
\hline lotarea & $\begin{array}{l}\text { Total area of the tax lot, expressed in square } \\
\text { feet rounded to the nearest integer }\end{array}$ \\
\hline DOFGrossFloorArea & $\begin{array}{l}\text { Self-reported total gross square footage } \\
\text { (square-foot) of the property. }\end{array}$ \\
\hline bldgarea & $\begin{array}{l}\text { The total gross area in square feet, except for } \\
\text { condominium measurements which come } \\
\text { from the Condo Declaration and are net square } \\
\text { footage not gross }\end{array}$ \\
\hline
\end{tabular}

\section{RESULTS AND DISCUSSIONS}

\section{A. Cluster Analysis}

The principal components obtained from the PCA are used for the clustering procedure. The result of the principal components was depicted as a variable factor map and is as shown in Figure 1. From Figure 1 and Table II we can see that the first five principal components account for more than $85 \%$ of the total variation of the data. Hence, we considered the first five principal components in our analysis. We obtained 4 clusters after performing HCPC. There were 5574 buildings in cluster 1, 1541 buildings in cluster 2, 3467 

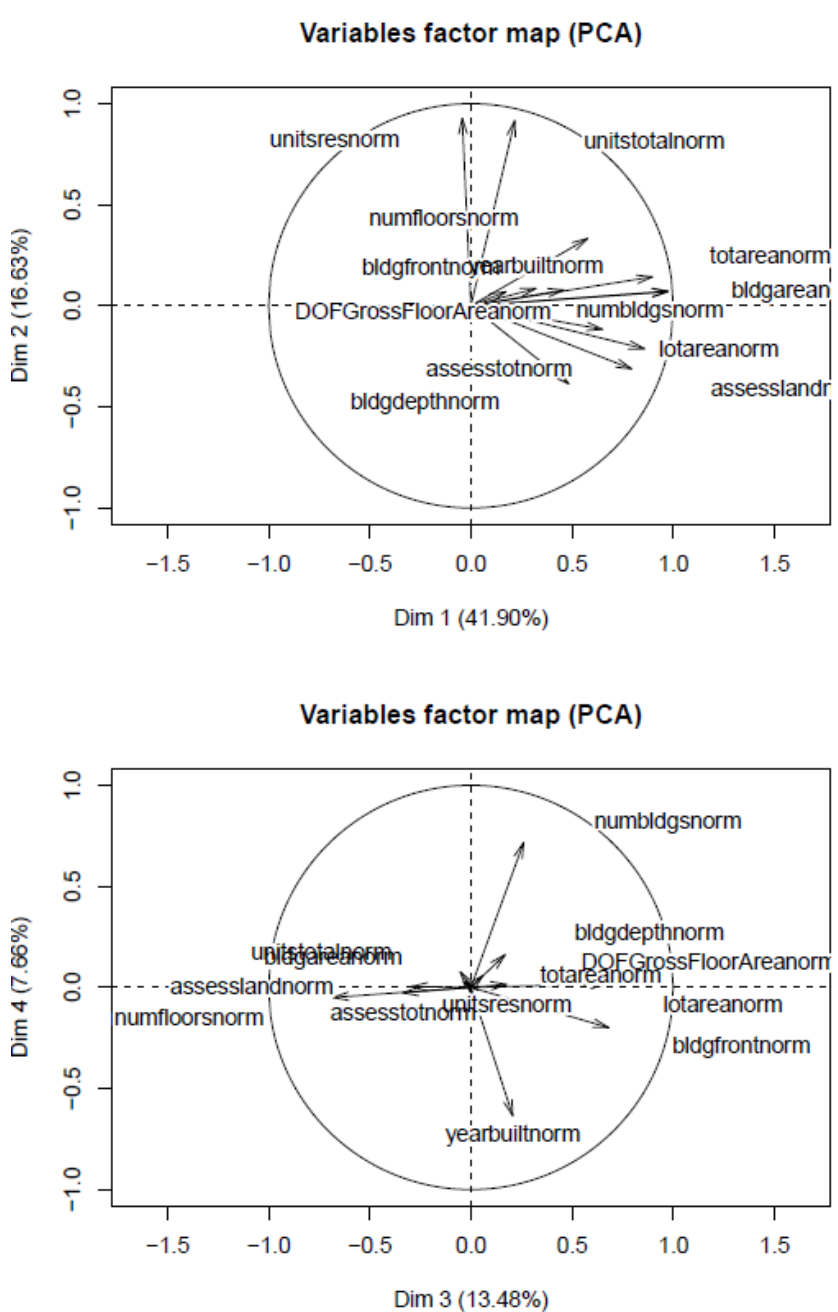

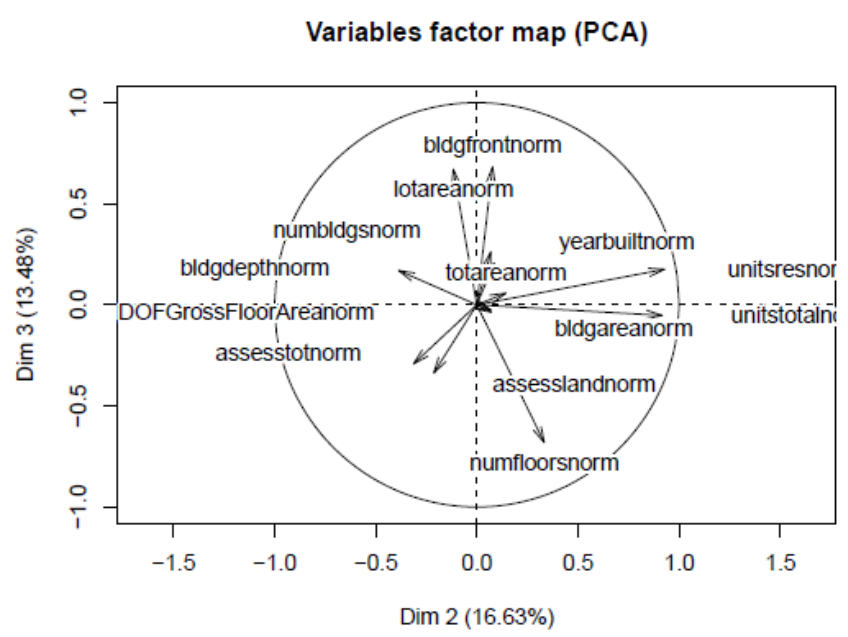

Variables factor map (PCA)

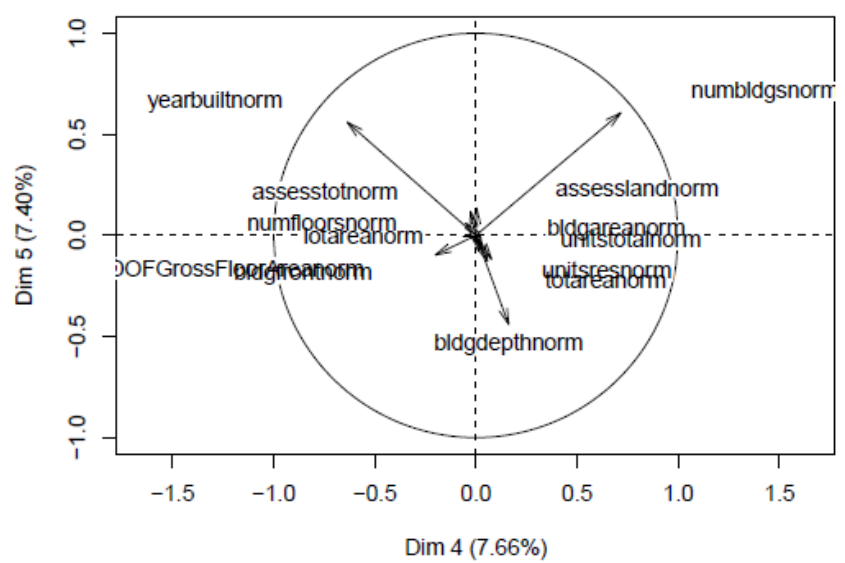

Fig. 1.Variables factor map

TableII: Principal components

\begin{tabular}{|l|l|l|l|l|l|}
\hline \multicolumn{7}{|c|}{ Principal Components } \\
\hline & Dim.1 & Dim.2 & Dim.3 & Dim.4 & Dim.5 \\
\hline Variance & 5.447 & 2.162 & 1.752 & 0.996 & 0.962 \\
\hline \% of var. & 41.89 & 16.63 & 13.476 & 7.665 & 7.403 \\
& 9 & & & & 79.67 \\
\hline Cumulative \% of var. & 41.89 & 58.53 & 72.006 & $\begin{array}{l}87.07 \\
3\end{array}$ \\
\hline
\end{tabular}

buildings in cluster 3 and 1349 buildings in cluster 4 . Cluster 1 is formed by the principal component dimensions 2,4,5,3 and 1 and cluster 4 is formed by dimensions 1,4 and 3 . Dimensions 3,5,4 and 2 constituted cluster 2 and dimensions $2,1,3,5$ and 4 constituted cluster 3 . The dimensions that represents the cluster 2 (which is 3,4,5 and 2) together captures less than $50 \%(45.17 \%)$ of the total variation of the individuals. Therefore, we did not consider cluster 2 in our further analysis. The cluster factor map is as shown in Figure 2. The Figure 2 also indicates the serial numbers of the buildings in the data frame.

The clusters 1,3 and 4 are characterized by the original variables as shown in Table III, IV and V.

In our further analysis, when we define the clusters, we define them using the variables that have mean higher or lower than the overall mean. Table VI aids in our analysis.

\section{B. Cluster Analysis}

For POLR, we mapped the weather site EUI, which is a continuous variable into an ordered multinomial variable by splitting them into three number of quantile groups called as levels (L). Buildings of level 3 has higher energy consumption than level 2 and level 1. Level 2 buildings consume more energy than buildings of level 1 . For cluster 1 , there were 1858 buildings in level 1, 1859 buildings in level 2 and 1857 buildings in level 3. For cluster 3, there were 1161 buildings

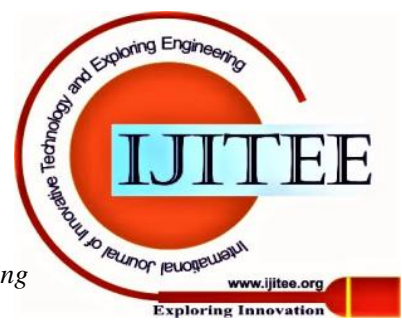


Evaluating the Significance of Financial Characteristics on Energy Consumption of Urban Building Stock using Principal Component Analysis and Logistic Regression

\section{Factor map}

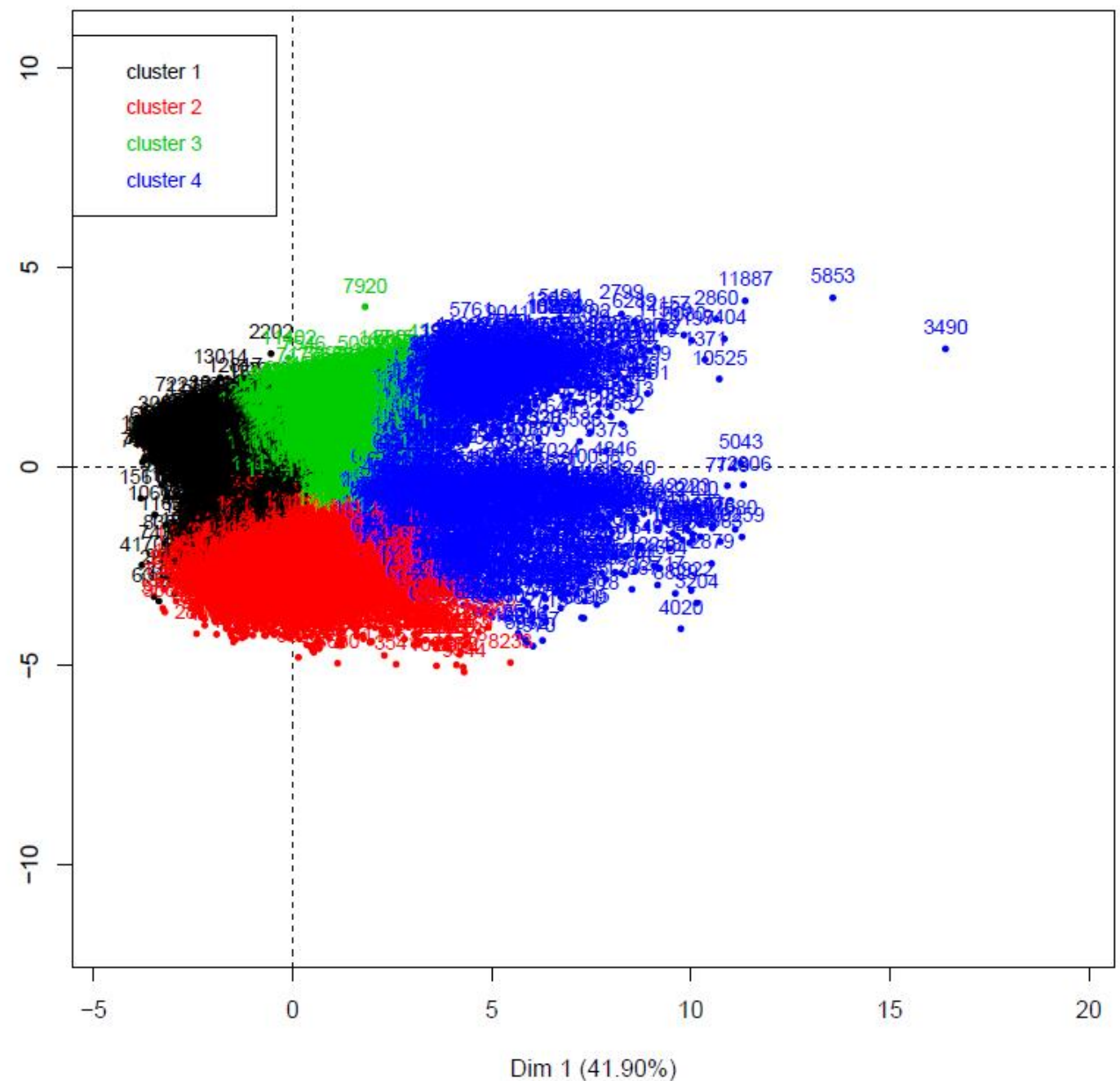

Fig. 2.Cluster factor map

Table- III: Cluster 1 charactersitics

\begin{tabular}{|c|c|c|c|c|}
\hline \multicolumn{5}{|c|}{ Cluster 1 } \\
\hline Original Variables & v.test & Mean.in.category & $\begin{array}{c}\text { Overall.me } \\
\text { an }\end{array}$ & p.value \\
\hline unitsresnorm & 18.17452 & 0.177691702 & $-1.11 \mathrm{E}-16$ & $8.21 \mathrm{E}-74$ \\
\hline unitstotalnorm & 7.117043 & 0.069583104 & $-1.34 \mathrm{E}-17$ & $1.10 \mathrm{E}-12$ \\
\hline numbldgsnorm & -7.25142 & -0.070896925 & $1.17 \mathrm{E}-17$ & $4.12 \mathrm{E}-13$ \\
\hline numfloorsnorm & -19.8972 & -0.194534679 & $-5.28 \mathrm{E}-17$ & $4.30 \mathrm{E}-88$ \\
\hline bldgdepthnorm & -36.9543 & -0.361300787 & $2.63 \mathrm{E}-16$ & $6.22 \mathrm{E}-299$ \\
\hline yearbuiltnorm & -37.2484 & -0.364176409 & $2.64 \mathrm{E}-14$ & $1.12 \mathrm{E}-303$ \\
\hline bldgfrontnorm & -51.382 & -0.502360511 & $7.05 \mathrm{E}-17$ & 0 \\
\hline assesslandnorm & -59.8157 & -0.584815848 & $1.54 \mathrm{E}-16$ & 0 \\
\hline totareanorm & -60.1599 & -0.588181005 & $4.78 \mathrm{E}-16$ & 0 \\
\hline assesstotnorm & -61.4193 & -0.600494945 & $-5.32 \mathrm{E}-16$ & 0 \\
\hline lotareanorm & -62.8956 & -0.614928393 & $7.77 \mathrm{E}-16$ & 0 \\
\hline DOFGrossFloorAreanorm & -67.4502 & -0.65945883 & $-7.05 \mathrm{E}-16$ & 0 \\
\hline bldgareanorm & -67.4851 & -0.659800083 & $-1.06 \mathrm{E}-16$ & 0 \\
\hline
\end{tabular}

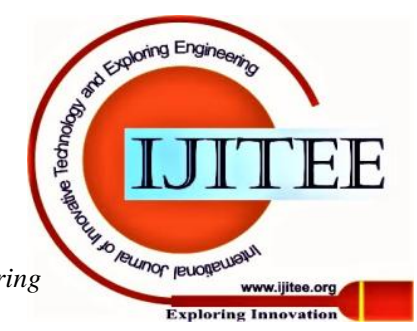


Table- IV: Cluster 3 charactersitics

\begin{tabular}{|c|c|c|c|c|}
\hline \multicolumn{5}{|c|}{ Cluster 3} \\
\hline Original Variables & v.test & Mean.in.category & Overall.mean & p.value \\
\hline unitstotalnorm & 41.438903 & 0.592762517 & $-1.34 \mathrm{E}-17$ & 0 \\
\hline unitsresnorm & 41.00593549 & 0.586569136 & $-1.11 \mathrm{E}-16$ & 0 \\
\hline bldgfrontnorm & 34.63072957 & 0.495375045 & $7.05 \mathrm{E}-17$ & $8.71 \mathrm{E}-263$ \\
\hline totareanorm & 23.88095498 & 0.341604964 & $4.78 \mathrm{E}-16$ & $4.83 \mathrm{E}-126$ \\
\hline DOFGrossFloorAreanorm & 22.75762861 & 0.32553635 & $-7.05 \mathrm{E}-16$ & $1.21 \mathrm{E}-114$ \\
\hline bldgareanorm & 22.70438582 & 0.324774739 & $-1.06 \mathrm{E}-16$ & $4.05 \mathrm{E}-114$ \\
\hline yearbuiltnorm & 22.60354441 & 0.323332253 & $2.64 \mathrm{E}-14$ & $4.00 \mathrm{E}-113$ \\
\hline lotareanorm & 22.06253524 & 0.315593391 & 7.77E-16 & 7.24E-108 \\
\hline numfloorsnorm & 9.943730119 & 0.142240023 & $-5.28 \mathrm{E}-17$ & $2.69 \mathrm{E}-23$ \\
\hline assesstotnorm & 5.388693406 & 0.07708253 & $-5.32 \mathrm{E}-16$ & 7.10E-08 \\
\hline assesslandnorm & 2.53587782 & 0.036274448 & $1.54 \mathrm{E}-16$ & $\begin{array}{c}0.01121658 \\
6 \\
\end{array}$ \\
\hline numbldgsnorm & -1.981925599 & -0.028350442 & $1.17 \mathrm{E}-17$ & $\begin{array}{c}0.04748756 \\
8 \\
\end{array}$ \\
\hline bldgdepthnorm & -4.97642735 & -0.071185273 & $2.63 \mathrm{E}-16$ & $6.48 \mathrm{E}-07$ \\
\hline
\end{tabular}

Table- V: Cluster 4 charactersitics

\begin{tabular}{|c|c|c|c|c|}
\hline \multicolumn{5}{|c|}{ Cluster 4} \\
\hline Original Variables & v.test & Mean.in.category & Overall.mean & p.value \\
\hline DOFGrossFloorAreanorm & 82.27389 & 2.109607 & $-7.05 \mathrm{E}-16$ & 0 \\
\hline bldgareanorm & 81.99923 & 2.102564 & $-1.06 \mathrm{E}-16$ & 0 \\
\hline totareanorm & 75.3834 & 1.932926 & $4.78 \mathrm{E}-16$ & 0 \\
\hline assesstotnorm & 75.22754 & 1.928929 & $-5.32 \mathrm{E}-16$ & 0 \\
\hline assesslandnorm & 68.44237 & 1.754949 & $1.54 \mathrm{E}-16$ & 0 \\
\hline numfloorsnorm & 62.19243 & 1.594693 & $-5.28 \mathrm{E}-17$ & 0 \\
\hline lotareanorm & 40.5363 & 1.039402 & $7.77 \mathrm{E}-16$ & 0 \\
\hline bldgdepthnorm & 38.67555 & 0.99169 & $2.63 \mathrm{E}-16$ & 0 \\
\hline bldgfrontnorm & 20.81467 & 0.533715 & $7.05 \mathrm{E}-17$ & $3.19 \mathrm{E}-96$ \\
\hline unitstotalnorm & 20.28185 & 0.520052 & $-1.34 \mathrm{E}-17$ & $1.86 \mathrm{E}-91$ \\
\hline yearbuiltnorm & 17.06012 & 0.437443 & $2.64 \mathrm{E}-14$ & $2.94 \mathrm{E}-65$ \\
\hline numbldgsnorm & 14.73797 & 0.3779 & $1.17 \mathrm{E}-17$ & $3.68 \mathrm{E}-49$ \\
\hline unitsresnorm & -8.85379 & -0.22702 & $-1.11 \mathrm{E}-16$ & $8.46 \mathrm{E}-19$ \\
\hline
\end{tabular}

Table- VI: Cluster charactersitics

\begin{tabular}{|c|c|c|c|c|}
\hline \multirow{2}{*}{ Building Characteristics } & \multicolumn{4}{|c|}{ Characteristics of the Cluster } \\
\hline & Cluster 1 & Cluster 2 & Cluster 3 & Cluster 4 \\
\hline unitsres & $\begin{array}{l}\text { Higher than the } \\
\text { overall mean }\end{array}$ & $\begin{array}{l}\text { Lower than the overall } \\
\text { mean }\end{array}$ & $\begin{array}{l}\text { Higher than the } \\
\text { overall mean }\end{array}$ & $\begin{array}{l}\text { Lower than the overall } \\
\text { mean }\end{array}$ \\
\hline unitstotal & $\begin{array}{l}\text { Higher than the } \\
\text { overall mean }\end{array}$ & $\begin{array}{l}\text { Lower than the overall } \\
\text { mean }\end{array}$ & $\begin{array}{l}\text { Higher than the } \\
\text { overall mean }\end{array}$ & $\begin{array}{l}\text { Higher than the overall } \\
\text { mean }\end{array}$ \\
\hline numbldgs & $\begin{array}{c}\text { Lower than the } \\
\text { overall mean }\end{array}$ & NA & $\begin{array}{c}\text { Lower than the } \\
\text { overall mean }\end{array}$ & $\begin{array}{l}\text { Higher than the overall } \\
\text { mean }\end{array}$ \\
\hline numfloors & $\begin{array}{l}\text { Lower than the } \\
\text { overall mean }\end{array}$ & $\begin{array}{l}\text { Lower than the overall } \\
\text { mean }\end{array}$ & $\begin{array}{l}\text { Higher than the } \\
\text { overall mean }\end{array}$ & $\begin{array}{l}\text { Higher than the overall } \\
\text { mean }\end{array}$ \\
\hline bldgdepth & $\begin{array}{l}\text { Lower than the } \\
\text { overall mean }\end{array}$ & $\begin{array}{l}\text { Higher than the } \\
\text { overall mean }\end{array}$ & $\begin{array}{l}\text { Lower than the } \\
\text { overall mean }\end{array}$ & $\begin{array}{l}\text { Higher than the overall } \\
\text { mean }\end{array}$ \\
\hline
\end{tabular}


Evaluating the Significance of Financial Characteristics on Energy Consumption of Urban Building Stock using Principal Component Analysis and Logistic Regression

\begin{tabular}{|c|c|c|c|c|}
\hline yearbuilt & $\begin{array}{l}\text { Lower than the } \\
\text { overall mean }\end{array}$ & $\begin{array}{l}\text { Higher than the } \\
\text { overall mean }\end{array}$ & $\begin{array}{l}\text { Higher than the } \\
\text { overall mean }\end{array}$ & $\begin{array}{l}\text { Higher than the overall } \\
\text { mean }\end{array}$ \\
\hline bldgfront & $\begin{array}{l}\text { Lower than the } \\
\text { overall mean }\end{array}$ & $\begin{array}{l}\text { Higher than the } \\
\text { overall mean }\end{array}$ & $\begin{array}{l}\text { Higher than the } \\
\text { overall mean }\end{array}$ & $\begin{array}{l}\text { Higher than the overall } \\
\text { mean }\end{array}$ \\
\hline asssessland & $\begin{array}{l}\text { Lower than the } \\
\text { overall mean }\end{array}$ & $\begin{array}{l}\text { Higher than the } \\
\text { overall mean }\end{array}$ & $\begin{array}{l}\text { Higher than the } \\
\text { overall mean }\end{array}$ & $\begin{array}{l}\text { Higher than the overall } \\
\text { mean }\end{array}$ \\
\hline totarea & $\begin{array}{l}\text { Lower than the } \\
\text { overall mean }\end{array}$ & $\begin{array}{c}\text { Lower than the overall } \\
\text { mean }\end{array}$ & $\begin{array}{l}\text { Higher than the } \\
\text { overall mean }\end{array}$ & $\begin{array}{l}\text { Higher than the overall } \\
\text { mean }\end{array}$ \\
\hline assesstot & $\begin{array}{l}\text { Lower than the } \\
\text { overall mean }\end{array}$ & $\begin{array}{l}\text { Higher than the } \\
\text { overall mean }\end{array}$ & $\begin{array}{l}\text { Higher than the } \\
\text { overall mean }\end{array}$ & $\begin{array}{l}\text { Higher than the overall } \\
\text { mean }\end{array}$ \\
\hline lotarea & $\begin{array}{l}\text { Lower than the } \\
\text { overall mean }\end{array}$ & $\begin{array}{l}\text { Higher than the } \\
\text { overall mean }\end{array}$ & $\begin{array}{l}\text { Higher than the } \\
\text { overall mean }\end{array}$ & $\begin{array}{l}\text { Higher than the overall } \\
\text { mean }\end{array}$ \\
\hline DOFGrossFloorArea & $\begin{array}{l}\text { Lower than the } \\
\text { overall mean }\end{array}$ & $\begin{array}{l}\text { Lower than the overall } \\
\text { mean }\end{array}$ & $\begin{array}{l}\text { Higher than the } \\
\text { overall mean }\end{array}$ & $\begin{array}{l}\text { Higher than the overall } \\
\text { mean }\end{array}$ \\
\hline bldgarea & $\begin{array}{l}\text { Lower than the } \\
\text { overall mean }\end{array}$ & $\begin{array}{l}\text { Lower than the overall } \\
\text { mean }\end{array}$ & $\begin{array}{l}\text { Higher than the } \\
\text { overall mean }\end{array}$ & $\begin{array}{l}\text { Higher than the overall } \\
\text { mean }\end{array}$ \\
\hline
\end{tabular}

\section{Cluster 1}

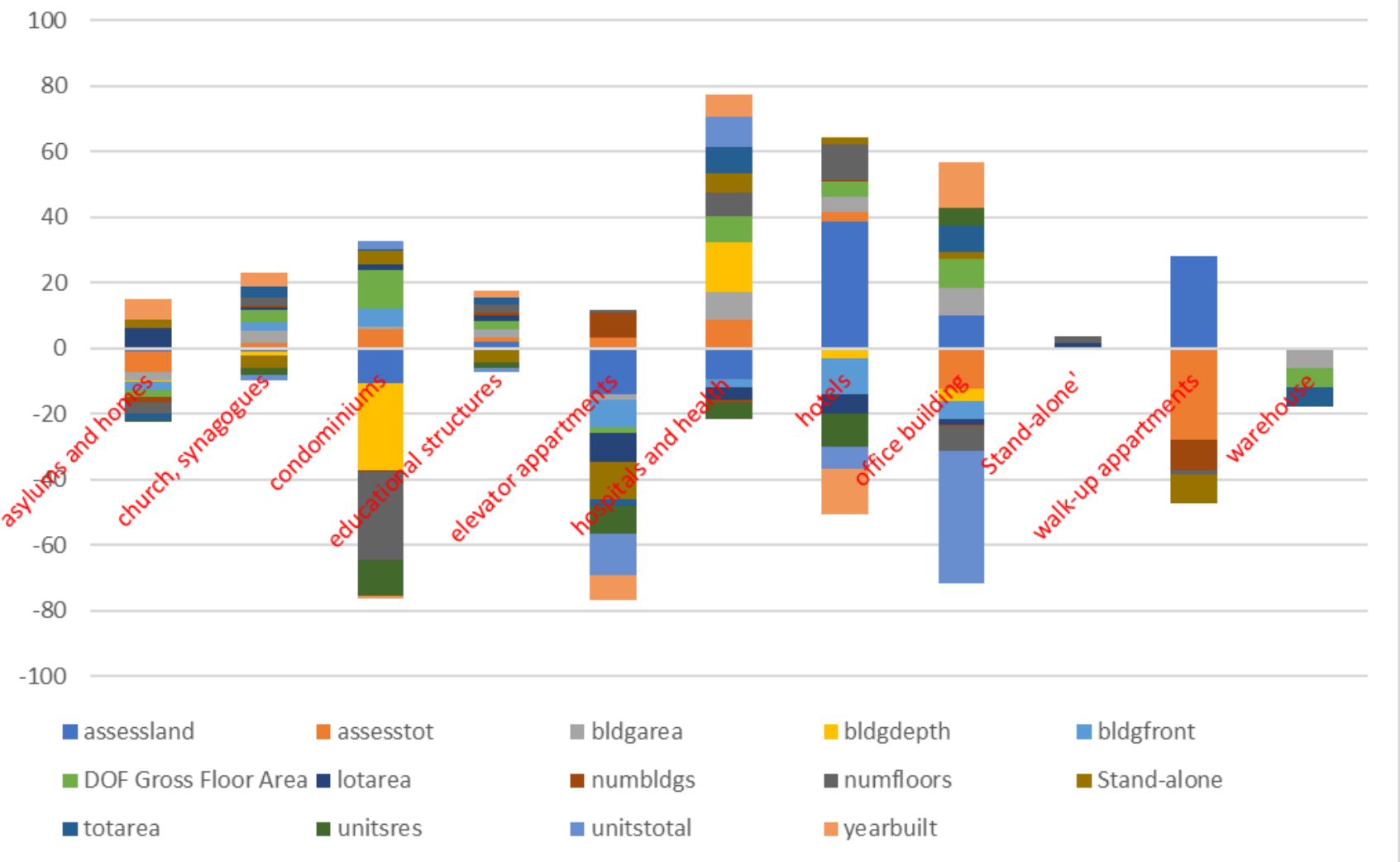

Fig. 3.Cluster 1 estimates 


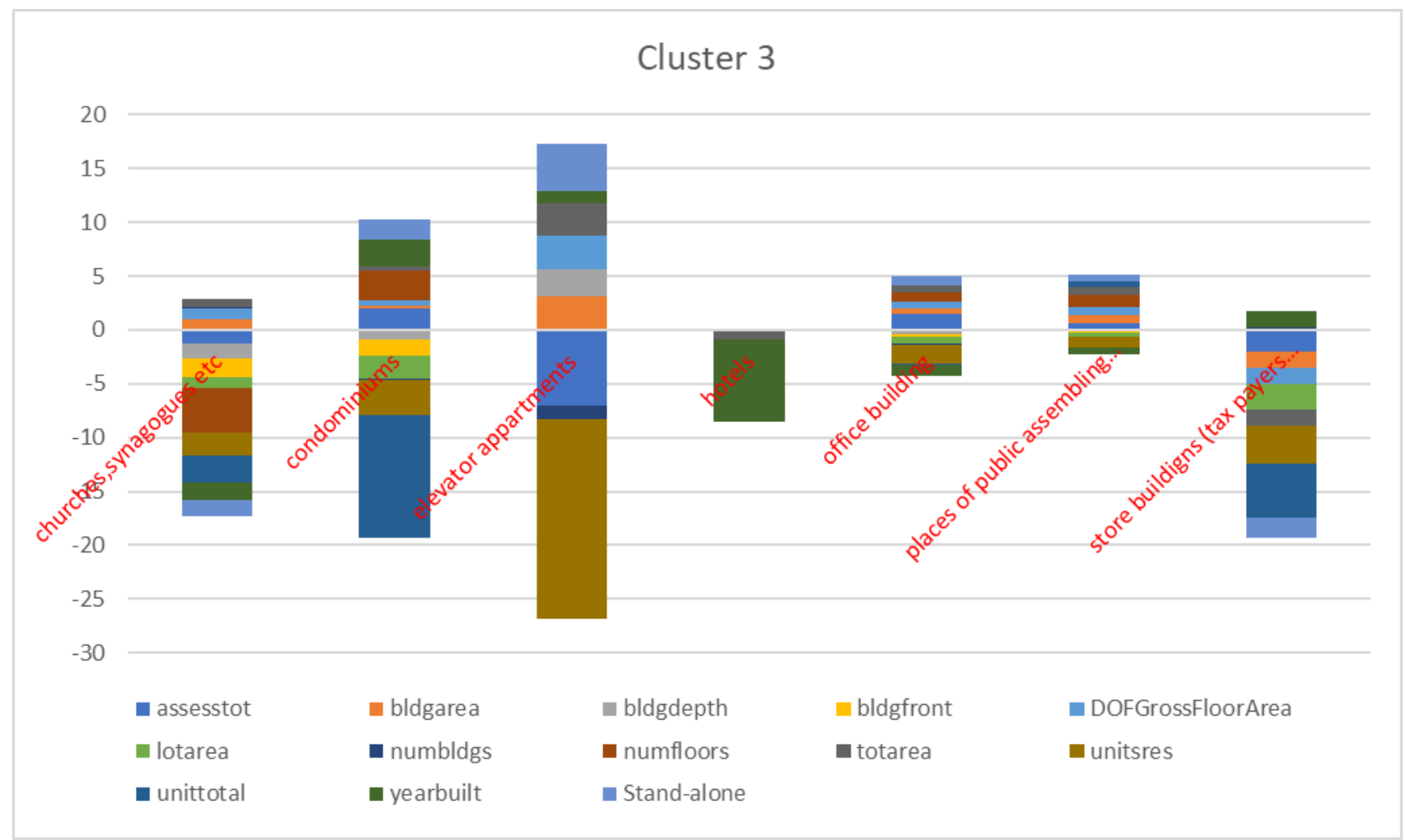

Fig. 4. Cluster 3 estimates

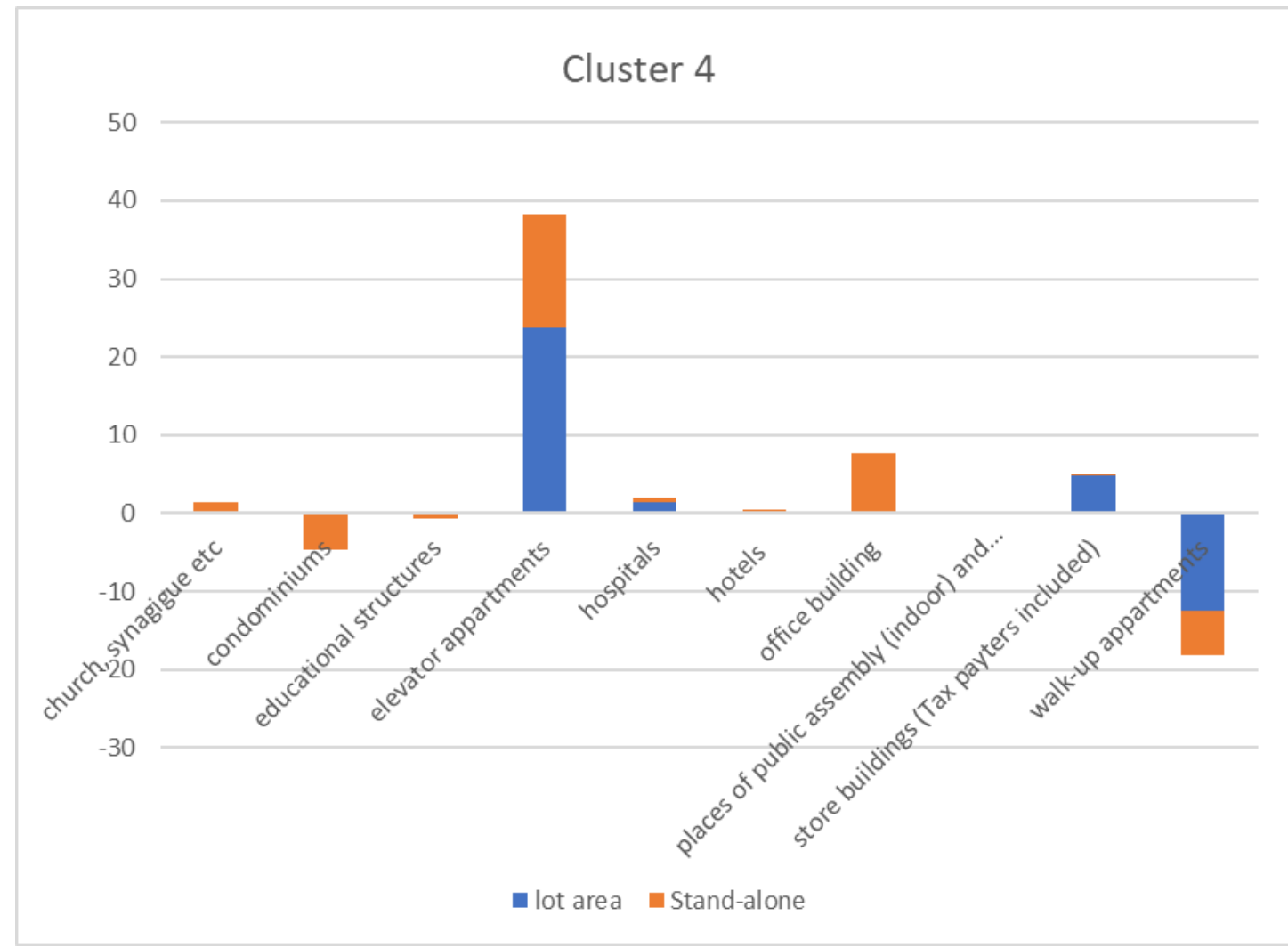

Fig. 5.Cluster 4 estimates

in level 1, 1154 buildings in level 2 and 1152 buildings in level 3. For cluster 4 , there were 452 buildings in level 1 , 449 buildings in level 2 and 448 buildings in level 3. These levels are the dependent variables in the POLR model.

The interaction of the building class with the variables mentioned in Table 1 is considered as the independent variable. For details regarding building class codes please refer to PLUTO data dictionary which is open source [13]. The model is as shown in equation (2).

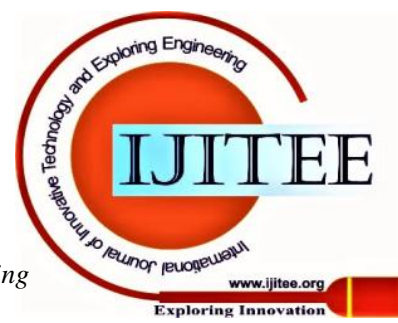


$\operatorname{logit}(P(L \leq n))=\beta_{0}+\beta_{1} *$ Builiding Class +

$\beta_{2} *$ unitsres $+\beta_{3} *$ unitstotal $+\beta_{4} *$ numbldgs +

$\beta_{5} *$ numfloors $+\beta_{6} *$ bldgdepth $+\beta_{7} *$

yearbuilt $+\beta_{8} *$ bld gfront $+\beta_{9} *$ assessland +

$\beta_{10} *$ bldgfront $+\beta_{11} *$ assessland $+\beta_{12} *$

totarea $+\beta_{13} *$ resarea $+\beta_{14} *$ comarea $+\beta_{15} *$

assesstot $+\beta_{16} *$ lotarea $+\beta_{17} *$

DOFGrossFloorArea $+\beta_{18} *$ bldgarea $+\beta_{19} *$

unitsres * Building Class $+\beta_{20} *$ unitstotal *

Building Class $+\beta_{21} *$ numbldgs *

Building Class $+\beta_{22} *$ numfloors *

Building Class $+\beta_{23} *$ bldgdepth $*$

Building Class $+\beta_{24}$ * yearbuilt *

Building Class $+\beta_{25} *$ bldgfront *

Building Class $+\beta_{26} *$ assessland *

Building Class $+\beta_{27} *$ bldgfront *

Building Class $+\beta_{28} *$ assessland *

Building Class $+\beta_{29} *$ totarea $*$ Building Class +

$\beta_{30} *$ resarea $*$ Building Class $+\beta_{31} *$ comarea $*$

Building Class $+\beta_{32} *$ assesstot *

Building Class $+\beta_{33} *$ lotarea $*$ Building Class +

$\beta_{34} *$ DOFGrossFloorArea $*$ Building Class +

$\beta_{35} *$ bldgarea $*$ Building Class

Where $\mathrm{L}$ denotes the various levels and $\mathrm{n}$ can take values 2 and 3. A pictorial representation of these estimates $(\beta)$ for various clusters are shown in Figure 3, 4 and 5 (for clusters 1, 3 and 4 respectively).

\section{Key Points}

1. Cluster 3 and 4 are characterized by higher assess land and assess tot value, in other words, higher financial characteristics than the overall mean. However, the financial characteristics in the cluster 1 are lesser than the overall mean (as in Table VI).

2. Elevator apartments consume more energy for the individual buildings in both cluster 3 and cluster 4 whereas less energy in the cluster 1 . However, the increase in the number of residential units and the total assess value of the elevator buildings reduces the energy consumption of the elevator buildings in cluster 3.The increase in the number of buildings in the tax lot of elevator apartments increases the energy consumption in the cluster 1 irrespective of the fact that the elevator apartments are lower in their energy consumption values in cluster 1.

3. Walk-up apartments consume less energy in both clusters 1 and cluster 4. However, an increase in the assess land value increases the energy consumption of the walk-up apartments.

4. Condominiums consume more energy in cluster 1 and cluster 3. However an increase in the total units, residential units, building front and building depth reduces the energy consumption in cluster 3 and the increase in the number of floors, building depth and assess value of the land reduces the energy consumption to a great extent in cluster 1 .

5. Office buildings consume more energy in the clusters 1,3 and 4. However, an increase in interaction with building front, year built (newer building), total units and residential units reduces the energy consumption in both the cluster 1 and 3 .
6. Hotels consume more energy in cluster 1 and cluster 4 . An increase in the building frontage, lot area, residential units, total units and the year built (newer building) reduces the energy consumption in cluster 1 . It is also noted that the interaction of year built (newer building) and total area decreases the energy consumption in cluster 3 .

The residential classes of buildings (elevator apartments, walk-up apartments, and condominiums) in the cluster with higher financial characteristics, other than the walk-up apartments have higher energy consumption (from key points 1 to 5). In those buildings an increase in the interaction with the other building characteristics such as building frontage, building depth and the number of residential units reduces the energy consumption. Even though a walk-up building tends to have higher energy consumption, the interaction with the financial characteristics reduces the energy consumption. Also, the elevator apartments in the cluster with lower financial characteristics increases the energy consumption of the buildings. However, the difference in the financial characteristics of the clusters doesn't influences the energy consumption of commercial buildings (other than the elevator apartments, walk-up apartments and condominiums) irrespective of the variation of financial characteristics in the clusters, as the building classes and their interactions with the various building characteristics shows the similar statistically significant estimates as outputs.

\section{CONCLUSION AND FUTURE SCOPE}

To promote Design for Energy Efficiency, it is imperative that we understand the building user energy consumption behavior along with the other building characteristics. These building energy consumption patterns are complex, and, in this study, we saw that this in many times are counter intuitive. In our study, we conclude that the financial characteristics have a significant effect in the energy consumption of the residential buildings, however, is not that significant in deciding the energy consumption of the commercial buildings. This helps the town planning officials to filter for design regarding the commercial and residential buildings, mandating energy retrofit measures to promote energy efficiency of the building stock. The significance of this study in a methodology point of view lies in the fact that, this study uses the open- data available to test this hypothesis regarding energy consumption using a combination of non-parametric machine learning algorithms and econometric models. The study in future can be extended to other cities where open data is available to test similar hypothesis.

\section{REFERENCES}

1. N. Koseleva and G. Ropaite, "Big Data in Building Energy Efficiency: Understanding of Big Data and Main Challenges," Procedia Eng., vol. 172, pp. 544-549, 2017.

2. A. N. Sadeghifam, S. M. Zahraee, M. M. Meynagh, and I. Kiani, "Combined use of design of experiment and dynamic building simulation in assessment of energy efficiency in tropical residential buildings," Energy Build., vol. 86, pp. 525-533, 2015.

Published By:

Blue Eyes Intelligence Engineering and Sciences Publication 
3. Z. Yang, J. Roth, and R. K. Jain, "DUE-B: Data-driven urban energy benchmarking of buildings using recursive partitioning and stochastic frontier analysis," Energy Build., vol. 163, pp. 58-69, 2018.

4. J. Ma and J. C. P. Cheng, "Identifying the influential features on the regional energy use intensity of residential buildings based on Random Forests," Appl. Energy, vol. 183, pp. 193-201, 2016.

5. Y. Hirano and T. Fujita, "Evaluation of the impact of the urban heat island on residential and commercial energy consumption in Tokyo," Energy, vol. 37, no. 1, pp. 371-383, 2012.

6. L. Pérez-Lombard, J. Ortiz, and C. Pout, "A review on buildings energy consumption information," Energy Build., vol. 40, no. 3, pp. 394-398, 2008.

7. A. F. Husson, J. Josse, and M. F. Husson, "Package ' missMDA ," 2019.

8. S. Lê, J. Josse, and F. Husson, "FactoMineR: an R package for multivariate analysis," J. Stat. Softw., vol. 25, no. 1, pp. 1-18, 2008.

9. F. Husson, S. Lê, and J. Pagès, Exploratory multivariate analysis by example using R. CRC press, 2017.

10. A. Irpino, R. Verde, and Y. Lechevallier, "Dynamic clustering of histograms using Wasserstein metric," in COMPSTAT, 2006, pp. 869-876.

11. B. Ripley et al., "Package 'mass," Cran R, vol. 538, 2013.

12. Constantine E. Kontokosta, "Predicting Building Energy Efficiency Using New York City Benchmarking Data," ACEEE Summer Study Energy Effic. Build., vol. 49, no. 2, pp. 15-19, 2012.

13. NYC Planning, "PLUTO data dictionary," 2017.

\section{AUTHORS PROFILE}

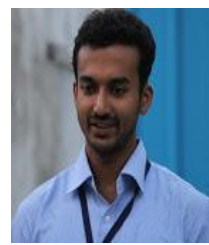

Vishnu Sivarudran Pillai is a $\mathrm{PhD}$ Student in the Department of Public Policy, Hong Kong University of Science and Technology (HKUST). Before joining as a $\mathrm{PhD}$ student in HKUST, he worked in Larsen and Toubro Constructions for five years. He has experience in working with steel plant construction projects, power plant construction projects and bridge construction projects. He did his M.Tech in Construction Technology and Management from the Department of Civil Engineering, National Institute of Technology Karnataka, India and his B.Tech in Mechanical Engineering from NSS College of Engineering, India. His research areas include construction management, building energy, Artificial Intelligence regulation, risk regulation, machine learning applications in risk and policy research. Best Paper - Runner's Up" at the Project Management Research and Academic Conference. He had received the Golden Paper (Best of the best paper) award at International Conference on Intelligence, Innovation and Inclusion - Best Practices for Global Excellence at the Pondicherry University and "Best Paper - Runner's Up" at the Project Management Research and Academic Conference 2017 organized by Project Management Institute in association with Indian Institute of Technology, Delhi on 3rd and 4th March'17 for presenting a paper on "Monitoring and Forecasting in Construction Projects using Risk Information Based Time Buffer"

Previous publications are:

1. Buffer on Project Monitoring and Forecasting of Steel Structures - A New Approach to Structural Planning. International Journal of Earth Sciences and Engineering, 9(3), 40-45.

2. Pillai, Vishnu S, Rajasekaran, C., \& Vatsa, P. K. (2016). Monitoring and Forecasting in Construction Projects Using Time Buffer. Journal of Construction Engineering, Technology and Management, 6(2), 9-16.

3. Pillai, Vishnu Sivarudran, \& Matus, K. (2019). Regulation of AI Technologies in the Construction Industry. HKUST IEMS Working Paper.

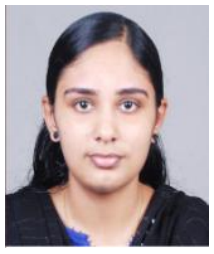

Arathi is currently working as a Design Engineer mainly concentrated in Traditional Architecture, in a Private Firm (Ezra Homes Architectural and Design Construction, India). She did her M.Tech in Industrial Engineering and Management from the Department of Mechanical Engineering (Rajiv Gandhi Institute of Technology, Government Engineering College, India). She did her B.Tech in Civil Engineering (St. Josephs College of Engineering, India). She also completed Post Graduate Diploma in Traditional Architecture. Her research areas are Construction Management, Total Quality Management and Stakeholder Management.

List of International Conferences attended in India:
1. ICRBS IIT ROORKEE; December (16,17) 2017 ("Whether Construction Sector Need's a TQM Model or Not: A case study")

2. ICAIEA 2018, Chennai; January $(3,4,5) 2018$ ("A conceptual Model Connecting TQM factors and Performance Parameters of Construction Firm")

3. PDME 2018, Thrissur, Kerala; January (18,19,20) 2018 ("Importance of Stakeholder Management in Construction Quality") 